\title{
Water: The Case for a New Taxonomy
}

\author{
Jonathan Steffen
}

Jonathan Steffen Limited, Cambridge, UK

\section{Water Is Life}

The Food and Agriculture Organization of the United Nations could not be clearer on the matter: "Water is life, in symbolic and material dimensions," it stated in 2015. "It is integral to human food security and nutrition and it is the lifeblood of ecosystems upon which all humans depend, including forests, lakes and wetlands" [1].

Essential to life, water is a natural resource that is coming under increasing pressure worldwide as a result of population growth, climate change and political and economic conflicts. It is a finite resource and the proportion of it that is accessible and potentially drinkable is very small. As the Global Water Partnership puts it: "The planet is $70 \%$ salt water. Only $3 \%$ of the world's water is freshwater, and of this, only about $1.5 \%$ is accessible. In other words, the rest is locked up in glaciers or in deep aquifers. Agriculture already uses some $70 \%$ of the world's water" [2]. The Global Water Partnership continues: “The same amount of water continuously circulates around the planet in what is known as the water cycle. But it is not just about supply [...] Water resources management is about a host of issues such as government policy, financing, allocation, transboundary conflict, and the ecosystem [...] Sustainable development will not be achieved without a water-secure world" [3].

A "water-secure" world can be achieved only if the world as a whole wakes up to the danger it is facing. Yet we have been flagrant in our misuse of water for generations, and if the Sahara Desert is the world's most famous

\section{KARGER}

๑) 2017 S. Karger AG, Basel

E-Mail karger@karger.com

www.karger.com/anm symbol of man's abuse of the planet's ecosystems, recent research indicates that many parts of the world today are susceptible to the threat of desertification [4]. The world needs to think about water in fresh terms. Yet we seem to use the same old words to describe a problem that is evolving at a dramatic pace on many fronts.

\section{Living or Dead?}

The Proto-Indo-European language had 2 root words for water: $a p$ - and wed-. The former referred to water as a living force; the latter, as an inanimate substance [5]. In this, we see humanity's ambivalence towards water, which has such power but at the same time seems intrinsically lacking in content. Water is not animate, yet it can move with terrific force and can change its state, existing as vapour and a solid as well as a liquid. Water is not a nutrient, but its existence is the prerequisite for accessing all forms of nutrition and therefore for facilitating all forms of growth. It would seem that the world shares a common understanding of this duality, a common grasp of the paradoxical power and inertness of water. Water is like nothing else on the planet - except, arguably, the very air that we breathe. The idea of being surrounded by water but unable to drink it is a timeless horror [6], while the discovery of water on Mars encourages some people to hope that there was once life on the Red Planet and that Mars might one day be populated by human beings [7]. 


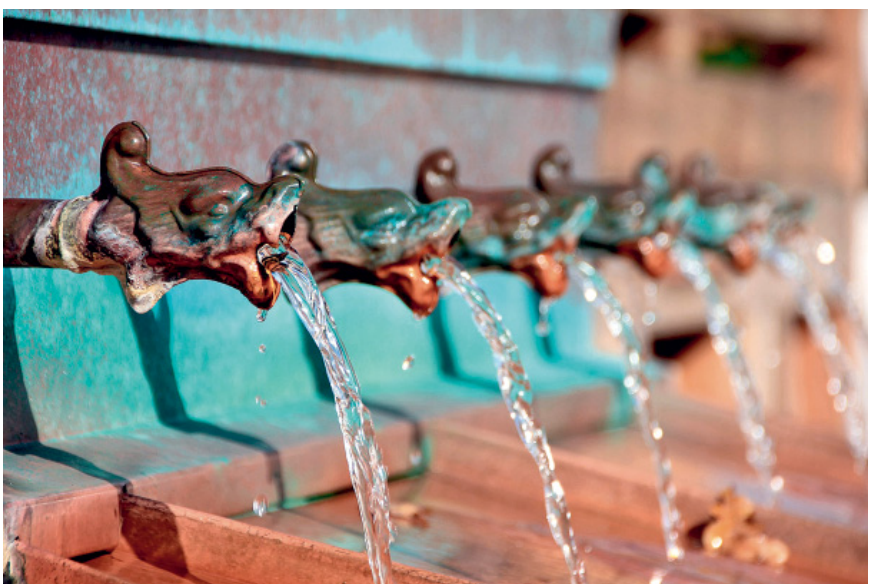

Fig. 1. "Water is life, in symbolic and material dimensions" (FAO).

\section{The Language of Water}

The English word "water" shares a common root with the Hittite watar [8], the Sanskrit udrah, the Greek hydor, the Russian voda, the Gaelic uisge and the Latin unda [9]. And in English today, there is still only one word for water: although "water" is used in many compound words (waterfall, waterline, waterway, etc.), the word "water" itself remains unchanged.

Everything in our linguistic usage points to the idea that water is the same substance wherever it is found: $\mathrm{H}_{2} \mathrm{O}$, nothing more and nothing less. True, hydrologists have their own technical language in which to discuss water management, and entire glossaries on the subject abound (for example, the water glossary of the US Geological Survey Water Science School) [10], but surprisingly few neologisms have been coined to describe the topic. The layperson may be familiar with, for instance, greywater ("wastewater from clothes washing machines, showers, bathtubs, hand washing, lavatories and sinks" [10]) - but if we consider the number of new words that have entered the language through the agency of information technology, it would seem that we are reluctant to put a great deal of effort into the reconceptualization or recategorization of water. And yet the Food and Agriculture Organization observes: "The many potential uses of water [...] typically require different quantities and qualities of water, and therefore often specific treatment" [11]. Specific linguistic treatment might also be in order.

Surely it might help if we started thinking about water in more imaginative ways? What if bottled water, potable tap water, non-potable tap water and non-potable non- tap water each had a different name? Such nomenclatural distinctions do exist if we think of the spectrum that links molasses to icing sugar, or crude oil to high-octane unleaded petrol. Would it not help it we had the same capacity of differentiation vis-à-vis water - a language that reflects the steps of the water value chain?

\section{Talking a New World Into Being}

If the world had a new language of water, it would be easier to talk about water utilisation, water wastage, water shortages, water pollution, water rights, and the like. It would be easier because we would have agreed categories into which to conceptually subdivide all the water in the world - different images with which to discuss the different qualities of water that we all need. Scientists sometimes create words to describe what they are looking for, long before they find it: prior to receiving its current name, and long before its existence had been proven, the Higgs boson was referred to as "the God particle" [12]. Why should not hydrologists do the same with water?

"Water security," states UN-Water, "encapsulates complex and interconnected challenges and highlights water's centrality for achieving a larger sense of security, sustainability, development and human well-being." The United Nations Inter-Agency Mechanism on all Freshwater Issues continues that: "many factors contribute to water security, ranging from biophysical to infrastructural, institutional, political, social and financial [...] Addressing this goal therefore requires interdisciplinary collaboration across sectors, communities and political borders, so that the competition or potential conflicts over water resources $[\ldots]$ is adequately managed in recognition of its security implications on tensions and conflicts" [13].

This is policy-speak - an abstract, Latinate form of discourse in which scientists and policy-makers discuss matters of global concern but a type of language that many people find alienating. Might we not have more productive debates if we had a more direct and at the same time more differentiated way of talking about water in all its many forms, a new taxonomy of water? After all, the IT revolution has given us an apparent torrent of neologisms or verbal repurposings, including app, Big Data, bitcoin, blog, bot, browser, bug, cache, clutter, code, cookie, crawler, cyberbully, dark web, debug, friend, google, hack, history, hotspot, instafamous, Instagram, internet, internet of things, iPlayer, iPod, junk, like, monitor, post, patch, selfie, smartphone, spam, tablet, text, touchscreen, trojan, tweet, virus, vlog, web, web trail, Wi-Fi, unfriend - and even, of course, password fatigue. 
So why not get the world talking? Why not try to create a vocabulary that might help us address the problems that we all face? If I were leading an organization involved in water, whether a non-governmental organization, a commercial entity, a state authority or a think tank, I would not be keeping quiet about this problem. I would be actively seeking to address it. We need to create the language that will allow us to solve a complex of problems that today seem all but insoluble - and so far, we have not brought much imagination to bear upon this issue.

So why not try open linguistic innovation on a global scale? Why not seek to pioneer a new taxonomy of water?
Once we have the words and the pictures that they create, we may be in a better position to start dealing with the problem.

\section{Disclosure Statement}

The author declares no conflicts of interest.

\section{Funding Sources} lishers.

The development of this letter was funded by Karger Pub-

\section{References}

1 United Nations Food and Agriculture Organization (FAO): Water for Food Security and Nutrition: A Report by the High Level Panel of Experts on Food Security and Nutrition, 2015, p 25. http://www.fao.org/3/a-av045e. pdf.

2 Website of the Global Water Partnership (GWP). http://www.gwp.org/en/About/why/ the-water-challenge/ (accessed May 12, 2017).

3 Website of the Global Water Partnership (GWP). http://www.gwp.org/en/About/why/ the-water-challenge/ (accessed May 12, 2017).

4 Website of Berkeley Energy \& Resources Collaborative (BERC). http://berc.berkeley.edu/ desertification-the-forgotten-side-ofclimate-change/ (accessed May 25, 2017).
5 Online Etymology Dictionary. http://www. etymonline.com/index.php?term $=$ water (accessed May 25, 2017).

6 "Water, water everywhere, / Nor any drop to drink." Coleridge ST: The Rime of the Ancient Mariner; in Wordsworth W, Coleridge ST (eds): Lyrical Ballads, with a Few Other Poems. London, 1798.

7 NASA Confirms Evidence That Liquid Water Flows on Today's Mars, September 28, 2015. https://www.nasa.gov/press-release/nasaconfirms-evidence-that-liquid-water-flowson-today-s-mars (accessed March 12, 2017).

8 University of Chicago - Chicago Hittite Dictionary Project. https://hittitedictionary. uchicago.edu/page/why-study-hittites (accessed May 12, 2017).

9 http://www.dictionary.com/browse/waters (accessed June 9, 2017).
10 https://water.usgs.gov/edu/dictionary.html (accessed May 25, 2017).

11 United Nations Food and Agriculture Organization (FAO): Water for Food Security and Nutrition: A Report by the High Level Panel of Experts on Food Security and Nutrition 2015, p 13. http://www.fao.org/3/a-av045e.pdf.

12 Forbes Leadership Forum, October 9, 2013. https://www.forbes.com/sites/forbesleadershipforum/2013/10/09/the-higgs-bosonwins-the-nobel-why-we-call-it-the-godparticle/\#5280e3823cbf (accessed June 9, 2017).

13 Website of UN-Water, The United Nations Inter-Agency Mechanism on all Freshwater Issues, Including Sanitation. http://www. unwater.org/topics/water-and-food/en/ (accessed May 12, 2017). 